\title{
Thermosensory Behaviour in Paramecium tetraurelia: a Quantitative Assay and Some Factors that Influence Thermal Avoidance
}

\author{
By TODD HENNESSEY AND D. L. NELSON \\ Department of Biochemistry, College of Agricultural and Life Sciences, 420 Henry Mall, \\ University of Wisconsin-Madison, Madison, Wisconsin 53706, U.S.A.
}

(Received 25 October 1978)

\begin{abstract}
The free-swimming ciliate Paramecium avoids warm regions. We have developed a quantitative assay of thermal avoidance, based on the interference between thermal avoidance and the normal tendency to swim upward (negative geotaxis). Paramecium tetraurelia swimming in a Tris $/ \mathrm{Ca}^{2+}$ solution avoided a region warmer than about $40{ }^{\circ} \mathrm{C}$. Several factors influenced the strength of the response, including the concentrations of monovalent cations and $\mathrm{Ca}^{2+}$, the temperature of the test region, and the temperature at which the animals had been cultured. At $1 \mathrm{mM}-\mathrm{Ca}^{2+}$, increasing $\mathrm{Na}^{+}$concentration enhanced avoidance of a $40{ }^{\circ} \mathrm{C}$ region, and at a constant $\mathrm{Na}^{+}$concentration $(0.5 \mathrm{~mm})$, avoidance improved with decreased $\mathrm{Ca}^{2+}$. When the ratio $\left[\mathrm{Na}^{+}\right] /\left[\mathrm{Ca}^{2+}\right]^{\frac{1}{2}}$ was held constant, varying $\mathrm{Na}^{+}$and $\mathrm{Ca}^{2+}$ concentrations did not affect thermal avoidance. Other monovalent cations $\left(\mathrm{Cs}^{+}, \mathrm{Li}^{+}, \mathrm{Rb}^{+}\right)$ and hydroxylamine also enhanced thermal avoidance, and $\mathrm{K}^{+}$was somewhat less effective than these. The strength of the avoidance response increased with increasing test temperature in the range of 37 to $42^{\circ} \mathrm{C}$ for cells grown at $28^{\circ} \mathrm{C}$. Cells grown at $15^{\circ} \mathrm{C}$ had a lower threshold for thermal avoidance, and those grown at $35^{\circ} \mathrm{C}$ showed no avoidance at $40^{\circ} \mathrm{C}$ and only poor avoidance at higher temperatures. Cells cultured at 15 or $35^{\circ} \mathrm{C}$ and then shifted to $28{ }^{\circ} \mathrm{C}$ acquired the thermal behaviour typical of cells cultured at $28{ }^{\circ} \mathrm{C}$. Behavioural mutants with defective $\mathrm{Ca}^{2+}$ channels (Pawns) are incapable of reversing their swimming direction and showed little or no thermal avoidance. We suggest that thermal avoidance is triggered by thermotropic phase transitions in the lipids of the excitable membrane of Paramecium tetraurelia.
\end{abstract}

\section{INTRODUCTION}

Early studies by Mendelssohn $(1902 a, b, c)$ and by Jennings $(1904,1906)$ established that the ciliate protozoon Paramecium avoids regions of extreme temperature and tends to aggregate in a region of intermediate temperature, which for cells grown at $24{ }^{\circ} \mathrm{C}$ is 24 to $28^{\circ} \mathrm{C}$. More recent studies (Tawada \& Oosawa, 1972; Tawada \& Miyamoto, 1973; Nakaoko \& Oosawa, 1977) have documented the fact that Paramecium can respond to very small thermal gradients by altering its swimming behaviour, but the means by which such small changes are detected, and the mechanism by which the thermal stimulus is transduced into a behavioural response, remain unknown. Extensive electrophysiological and genetic studies of Paramecium have yielded strong evidence that a variety of chemical and physical stimuli cause depolarization of the surface membrane and the opening of a voltage-sensitive $\mathrm{Ca}^{2+}$ channel. The resulting influx of $\mathrm{Ca}^{2+}$ raises the internal $\mathrm{Ca}^{2+}$ concentration above a critical value, bringing about a temporary reversal in the direction of the effective stroke of the several thousand cilia and a reversal in the swimming direction, followed by forward motion in a new direction (Naitoh, 1968; Eckert, 1972; Kung et al., 1975; Nelson \& Kung, 1978). The result of such avoiding reactions is net motion away from the stimulus. 


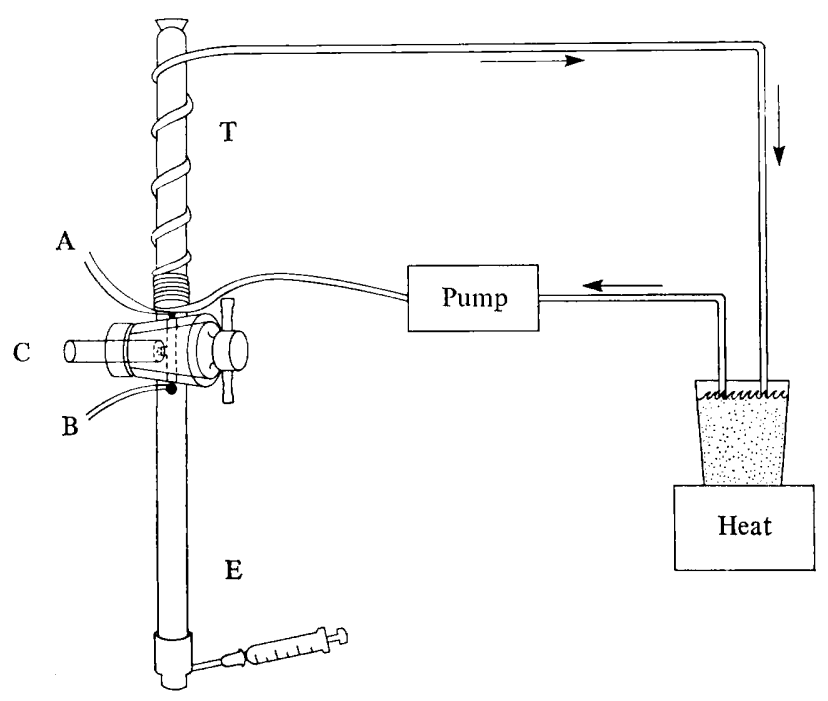

Fig. 1. T-tube for assaying thermal avoidance. The test $\operatorname{arm}(\mathrm{T})$ was heated by pumping hot water through tubing wrapped around it until the test temperature was reached at thermistor A; temperature in the entry arm (E) was monitored with a thermistor at B. Cells were then injected into the entry arm, as described in Methods. After $5 \mathrm{~min}$, the stopcock was closed and cells were removed for counting from arms E, $T$ and the unheated control arm (C).

Thermotaxis has been observed in several other simple organisms, including the slime mould Physarum polycephalum (Tso \& Mansour, 1975), the nematode Caenorhabditis elegans (Hedgecock \& Russell, 1975), the cellular slime mould Dictyostelium discoideum (Poff \& Skokut, 1977), Chlamydomonas (Oosawa, 1976) and Escherichia coli (Maeda et al., 1976). The temperature at which thermal avoidance occurs depends on the growth temperature in Paramecium (Jennings, 1904; Tawada \& Oosawa, 1972), and in Dictyostelium discoideum, Poff \& Skokut (1977) have suggested a possible role for membrane lipid in thermosensory transduction.

We have devised a quantitative assay for thermal avoidance in Paramecium and have used it to study some of the factors, including growth temperature, which govern this behaviour. We have also begun to study thermal avoidance in mutants originally selected for defective swimming behaviour in response to other types of stimuli, as well as mutants selected for defective thermal avoidance.

\section{METHODS}

Cells and culture media. Paramecium tetraurelia (formerly $P$. aurelia, species 4 ), stock $51 \mathrm{~s}$ and mutants Pawn A (d4-94) and Pawn B (d4-95) were gifts from C. Kung. They were grown at $28^{\circ} \mathrm{C}$ in Cerophyl medium (Sonneborn, 1950) with Enterobacter cloacae.

Solutions. The control solution contained $1 \mathrm{mM}-\mathrm{Ca}(\mathrm{OH})_{2}, 1 \mathrm{~mm}$-citric acid and $1 \mathrm{~mm}-T$ ris in deionized, distilled water. This solution was chosen to allow direct comparisons of our experiments with electrophysiological studies in which the same solution was used. All solutions were adjusted to $\mathrm{pH} 7.0$ with Tris or $\mathrm{HCl}$, except in the experiment with 3-( $N$-morpholino)propanesulphonic acid (MOPS) buffer, which was adjusted to $\mathrm{pH} 7.0$ with citric acid. Cations were added as chloride salts.

T-tube assay apparatus. The test apparatus was similar to that used by Van Houten et al. (1975) to study chemotaxis'in Paramecium. A T-shaped tube was fashioned from a two-way stopcock shell (Pyrex S8702) by attaching an extra arm (C) at the stopcock (see Fig. 1). This added arm was $5.9 \mathrm{~cm}$ long, $0.5 \mathrm{~cm}$ in diameter, and held a volume of $1.2 \mathrm{ml}$. The other two arms were $11 \mathrm{~cm}$ long, $0.65 \mathrm{~cm}$ in diameter, and held $3.7 \mathrm{ml}$ each. A Teflon three-way stopcock plug with an inner diameter of $1 \mathrm{~mm}$ was used with this T-tube shell. To eliminate thermal convection, the T-tube was used in a vertical position so that the uppermost arm was the test arm (T) (i.e. the heated arm) and the lower arm was the entry arm (E). The small arm perpendicular to these two opposing arms was the control arm (C) (Fig. 1). Two thermistors (Fenwal Electronics 
GB32J2) were embedded in epoxy near the three-way stopcock (A, B) to monitor the temperatures on both the $T$ and $E$ sides. The temperature was measured with a digital voltmeter accurate to within $\pm 0.05^{\circ} \mathrm{C}$.

The thermistor at $\mathrm{T}$ was used routinely to monitor temperature in the heated arm, but to avoid obstructing the path of cells entering the $\mathrm{T}$ arm from the stopcock, the thermistor was placed several millimetres above and to the side of the stopcock opening. To determine the actual temperature at the stopcock opening, in a separate experiment we positioned a thermistor at the opening and recorded its output and that of the permanently mounted thermistor as the temperature in $T$ was varied. From the calibration curve thus obtained, it was possible to approximate $\left( \pm 0 \cdot 2^{\circ} \mathrm{C}\right)$ the temperature at the stopcock opening using a thermistor several millimetres away, out of the swimming path. The temperatures reported here are the temperatures at the stopcock opening, where the avoidance presumably occurs.

$T$-tube assay of thermotaxis. Cells were harvested in the exponential phase of growth (1500 to 2000 cells $\mathrm{ml}^{-1}$ ) by centrifugation in a $100 \mathrm{ml}$ pear-shaped vessel in an oil-testing centrifuge (International HN-S) for $2 \mathrm{~min}$ at $500 \mathrm{rev} . \mathrm{min}^{-1}$, washed in control solution, then suspended in control solution at a density of about 20000 cells $\mathrm{ml}^{-1}$. In most experiments, cells were held in this control solution at room temperature (25 to $28^{\circ} \mathrm{C}$ ) for $60 \mathrm{~min}$ before thermotaxis assays. For the last $30 \mathrm{~min}$ of this pre-incubation, air was bubbled into the suspension with a fine capillary to ensure uniform suspension.

The test arm was filled with the solution to be tested, then sealed with a Parafilm-covered cork. The rest of the T-tube apparatus was filled with the same solution, the entry arm was closed with a serum stopper, and the control arm was left open. Tygon tubing ( $\left(\frac{1}{16}\right.$ in diam., $\frac{1}{32}$ in wall) was wrapped around the test arm near the stopcock and distilled water at 80 to $90^{\circ} \mathrm{C}$ was circulated through the tubing with a peristaltic pump to heat the arm. The temperature at the thermistor in $\mathrm{T}$ was monitored and adjusted by altering the pump speed. During this heating the T-tube was mounted in a vertical position with the stopcock open and the test arm uppermost.

When the required temperature was reached at the test arm thermistor, the cells were injected slowly through the side of the serum stopper at the bottom of the entry arm (at room temperature) from a $1 \mathrm{ml}$ syringe with a 20 gauge needle. Fluid displaced by the injection flowed out the control arm and the temperature of the test arm did not change. The temperatures at both thermistors were logged every minute and 5 min after injection of the cells the stopcock was closed to terminate the assay. The thermistor near the top of the entry arm (B) read between 28 and $31{ }^{\circ} \mathrm{C}$ in all experiments. Cells were removed from each of the three arms and counted after dilution and immobilization in $1.0 \mathrm{mM}-\mathrm{NiCl}_{2}$.

From the numbers of cells in each arm, we calculated an 'index of thermotaxis', $I_{\mathbf{T}}$ :

$$
I_{\mathrm{T}}=\frac{\text { cells in } \mathrm{T}}{\text { cells in } \mathrm{C}+\text { cells in } \mathrm{T}}
$$

When $I_{\mathbf{T}}$ is near unity, little thermal avoidance has occurred; with effective thermal avoidance, the value of $I_{\mathrm{T}}$ approaches zero. In control experiments with all three arms at the same temperature (room temperature), $I_{\mathrm{T}}$ was approximately 0.93 . To control for variations in the rate of migration upward, the fraction of cells that escaped from the entry arm was measured, and expressed as $I_{\mathrm{M}}$ :

$$
I_{M}=\frac{\text { cells in } \mathrm{T}+\text { cells in } \mathrm{C}}{\text { total cells }(\mathrm{T}+\mathrm{C}+\mathrm{E})}
$$

$I_{M}$ is obviously a function of the length of the assay, as well as the swimming velocity and the frequency of direction changes. In control solution, $I_{\mathrm{M}}$ was $0 \cdot 1$ to 0.2 for most of our experiments lasting 5 min. Paramecium showed very strong negative geotaxis under these conditions; with all arms at the same temperature, virtually all cells injected into arm $E$ had entered $T$ or $C$ within $30 \mathrm{~min}$. When the $T$ arm was heated, the natural tendency to swim upward was counterbalanced by the tendency to avoid the warm region, and $I_{\mathrm{T}}$ decreased.

'Hot wire' assay of thermotaxis. The procedure for dark-field photography was adapted from that of Chang \& Kung (1973). A shallow glass-bottomed trough $6.3 \mathrm{~cm}$ long, $0.8 \mathrm{~cm}$ wide and $2 \mathrm{~mm}$ deep was mounted on a tripod beneath a Polaroid MP-4 Land camera with a $35 \mathrm{~mm}$ lens. The solutions in the trough were the same as previously described except that $0.02 \%$ methocel was added to reduce convection currents. A Nichrome wire bisecting the trough in the viewing area of the camera was heated electrically ( 2 to $3 \mathrm{~V}$ ) until the temperature near the wire, measured with a thermistor embedded in the trough wall, was $40^{\circ} \mathrm{C}$. Cells were suspended in control solution as previously described and 2 drops of this suspension were added to one side of the trough. Photographs were taken by exposing no. 42 Polaroid film (ASA200) for 4 to $5 \mathrm{~s}$.

Growth at high and low temperatures. An exponental phase culture at $28{ }^{\circ} \mathrm{C}$ was used to inoculate Cerophyl medium previously inoculated with bacteria, and these cultures were then incubated at 15 or $35^{\circ} \mathrm{C}$. This procedure was repeated for each series of experiments to avoid enrichment for thermotolerant mutants. 


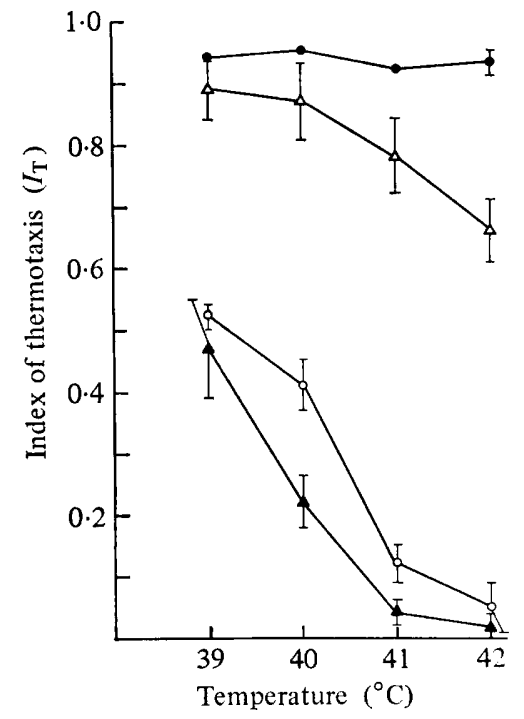

Fig. 2. Thermal avoidance in the T-tube. The wild-type (51s) and Pawn A and B mutants (d4-94 and $\mathrm{d} 4-95$, respectively) were tested for thermal avoidance at four temperatures. The wild-type was assayed without added $\mathrm{Na}^{+}(\mathrm{O})$ and with $0.5 \mathrm{~mm}-\mathrm{Na}^{+}(\mathbf{\Delta})$. Since Pawn mutants showed very poor avoidance at 0 or $0.5 \mathrm{~mm}-\mathrm{Na}^{+}, 1 \mathrm{~mm}-\mathrm{Na}^{+}$was added in the experiments with Pawn $A(\triangle)$ and Pawn B (O) mutants, to obtain a maximum estimate of thermotactic ability. Mean values \pm standard deviations are shown; the number of experiments, $n$, was 4 , except for the wild-type at $40^{\circ} \mathrm{C}(n=8)$ and for Pawn B for all temperatures except $42^{\circ} \mathrm{C}(n=1)$. With no heat applied to the test arm: $I_{\mathrm{T}}=0.92 \pm 0.03, I_{\mathrm{M}}=0.16 \pm 0.06$ for the wild-type in $0.5 \mathrm{mM}-\mathrm{Na}^{+} ; I_{\mathrm{T}}=0.95 \pm 0.01$, $I_{M}=0.21 \pm 0.03$ for the wild-type in control solution; $I_{\mathrm{T}}=0.93 \pm 0.02, I_{\mathrm{M}}=0.17 \pm 0.01$ for Pawn A; $I_{\mathrm{T}}=0.95 \pm 0.02, I_{\mathrm{M}}=0.19 \pm 0.03$ for Pawn B.

Exponential growth rates at $15^{\circ} \mathrm{C}$ were about three times lower than at $28^{\circ} \mathrm{C}$, and twice as high at $35^{\circ} \mathrm{C}$ relative to $28^{\circ} \mathrm{C}$. Cultures were harvested and washed as described above, but were pre-incubated at room temperature in control solution for only $5 \mathrm{~min}$ before assays, to avoid adaptation to room temperature.

\section{RESULTS}

\section{Thermal avoidance in the T-tube apparatus}

When all three arms of the test apparatus contained the same solution (control solution plus $0.5 \mathrm{mM}-\mathrm{Na}^{+}$) at the same temperature (room temperature), the observed $I_{\mathrm{T}}$ was 0.92 \pm 0.03 and $I_{M}$ was $0.16 \pm 0.06$. When the test arm was heated at $40^{\circ} \mathrm{C}$, there was no significant change in $I_{\mathrm{M}}$, but $I_{\mathrm{T}}$ decreased to $0 \cdot 22 \pm 0.04$, indicating effective thermal avoidance. In control solution (no added $\mathrm{Na}^{+}$), measurable thermal avoidance occurred at $39{ }^{\circ} \mathrm{C}$, and avoidance increased at higher temperatures (Fig. 2). The addition of $0.5 \mathrm{~mm}-$ $\mathrm{Na}^{+}$to the test solution had no effect at $39^{\circ} \mathrm{C}$ but significantly enhanced thermal avoidance at 40 and $41{ }^{\circ} \mathrm{C}$ (Fig. 2); at $42^{\circ} \mathrm{C}$ avoidance was virtually complete with or without added $\mathrm{Na}^{+}$. The index of motility $\left(I_{\mathrm{M}}\right)$ was not a function of temperature and did not change significantly on addition of $0.5 \mathrm{mM}-\mathrm{Na}^{+}$. The mean $I_{M}$ was $0.13 \pm 0.04$ in control solution and $0.09 \pm 0.04$ in $0.5 \mathrm{~mm}-\mathrm{Na}^{+}$.

\section{Effect of cations and hydroxylamine on thermal avoidance}

With the test arm at $40^{\circ} \mathrm{C}$, thermal avoidance increased on addition of $\mathrm{Na}^{+}$to the test solution at concentrations above $0.125 \mathrm{~mm}$ (Table 1 ). In controls with no heat applied to the test $\operatorname{arm}, I_{\mathrm{T}}$ was about 0.93 at all $\mathrm{Na}^{+}$concentrations. $I_{\mathrm{M}}$ was the same whether the test arm was heated or not, but decreased at $\mathrm{Na}^{+}$concentrations above $1 \mathrm{~mm}$, presumably as a result of more frequent direction changes (ciliary reversals). 
Table 1. Effect of monovalent cations and hydroxylamine on thermal avoidance in Paramecium tetraurelia

The index of thermotaxis $\left(I_{\mathrm{T}}\right)$ and the index of motility $\left(I_{\mathrm{M}}\right)$ were determined as described in Methods. The test arm (T) was either heated to $40^{\circ} \mathrm{C}$ or unheated. Cations were added to the control solution as indicated. All values given are means \pm standard deviations; $n$ is the number of independent trials.

\begin{tabular}{|c|c|c|c|c|c|}
\hline \multirow[b]{2}{*}{ Addition } & \multirow[b]{2}{*}{$n$} & \multicolumn{2}{|c|}{$\mathrm{T}$ arm at $40^{\circ} \mathrm{C}$} & \multicolumn{2}{|c|}{$\mathbf{T}$ arm unheated } \\
\hline & & $\boldsymbol{I}_{\mathrm{T}}$ & $I_{M}$ & $I_{\mathrm{T}}$ & $I_{\mathbf{M}}$ \\
\hline None (control) & 8 & $0.41 \pm 0.04$ & $0.17 \pm 0.03$ & $0.95 \pm 0.01$ & $0.21 \pm 0.03$ \\
\hline $0.063 \mathrm{mM}^{-\mathrm{Na}^{+}}$ & 8 & $0 \cdot 37 \pm 0 \cdot 10$ & $0.15 \pm 0.03$ & $0.93 \pm 0.02$ & $0 \cdot 19 \pm 0.04$ \\
\hline $0.125 \mathrm{mM}-\mathrm{Na}^{+}$ & 8 & $0.34 \pm 0.09$ & $0.15 \pm 0.03$ & $0.94 \pm 0.01$ & $0.20 \pm 0.02$ \\
\hline $0.25 \mathrm{~mm}-\mathrm{Na}^{+}$ & 8 & $0.29 \pm 0.07$ & $0 \cdot 14 \pm 0.04$ & $0.95 \pm 0.02$ & $0 \cdot 17 \pm 0.06$ \\
\hline $0.5 \mathrm{~mm}-\mathrm{Na}^{+}$ & 8 & $0.22 \pm 0.04$ & $0.12 \pm 0.05$ & $0.92 \pm 0.03$ & $0.16 \pm 0.06$ \\
\hline $1.0 \mathrm{~mm}-\mathrm{Na}^{+}$ & 8 & $0.12 \pm 0.07$ & $0.04 \pm 0.02$ & $0.95 \pm 0.01$ & $0.08 \pm 0.03$ \\
\hline $2 \cdot 0 \mathrm{mM}-\mathrm{Na}^{+}$ & 8 & $0.06 \pm 0.03$ & $0.03 \pm 0.03$ & $0.89 \pm 0.03$ & $0.05 \pm 0.03$ \\
\hline $0.5 \mathrm{~mm}^{-\mathrm{Cs}^{+}}$ & 4 & $0 \cdot 11 \pm 0.07$ & $0.06 \pm 0.02$ & $0.93 \pm 0.02$ & $0.10 \pm 0.03$ \\
\hline $0.5 \mathrm{mM}^{-\mathrm{Li}^{+}}$ & 4 & $0.14 \pm 0.04$ & $0.02 \pm 0.01$ & $0.94 \pm 0.02$ & $0.06 \pm 0.01$ \\
\hline $0.5 \mathrm{mM}^{-\mathrm{Rb}^{+}}$ & 4 & $0 \cdot 18 \pm 0.09$ & $0.11 \pm 0.03$ & $0.90 \pm 0.02$ & $0.13 \pm 0.04$ \\
\hline $0.5 \mathrm{mM}-\mathrm{NH}_{2} \mathrm{OH}$ & 4 & $0 \cdot 11 \pm 0.03$ & $0.11 \pm 0.02$ & $0.92 \pm 0.01$ & $0.14 \pm 0.05$ \\
\hline $0.5 \mathrm{mM}-\mathrm{K}^{+}$ & 4 & $0.37 \pm 0.04$ & $0.14 \pm 0.02$ & $0.93 \pm 0.01$ & $0.25 \pm 0.04$ \\
\hline $1.0 \mathrm{~mm}-\mathrm{K}^{+}$ & 4 & $0 \cdot 19 \pm 0.08$ & $0 \cdot 10 \pm 0.02$ & $0.93 \pm 0.01$ & $0.24 \pm 0.06$ \\
\hline
\end{tabular}

\section{Table 2. Effect on thermal avoidance of different $\mathrm{Na}^{+}$and $\mathrm{Ca}^{2+}$ concentrations}

For details, see legend to Table 1, except that the $\mathrm{Ca}^{2+}$ and $\mathrm{Na}^{+}$concentrations in the control solution were varied as indicated. For all experiments there were four independent trials.

\begin{tabular}{|c|c|c|c|c|c|}
\hline \multirow[b]{2}{*}{ Additions } & \multirow[b]{2}{*}[\mathrm{Na}^{+}]{$/\left[\mathrm{Ca}^{2+}\right]^{\frac{1}{2}}$} & \multicolumn{2}{|c|}{$\mathrm{T}$ arm at $40^{\circ} \mathrm{C}$} & \multicolumn{2}{|c|}{$\mathrm{T}$ arm unheated } \\
\hline & & $I_{T}$ & $I_{M}$ & $I_{\mathrm{T}}$ & $I_{M}$ \\
\hline $0.5 \mathrm{~mm}-\mathrm{Na}^{+}, 2.0 \mathrm{~mm}-\mathrm{Ca}^{2+}$ & $0 \cdot 354$ & $0.36 \pm 0.06$ & $0 \cdot 18 \pm 0 \cdot 03$ & $0.93 \pm 0.01$ & $0 \cdot 18 \pm 0.03$ \\
\hline $0.707 \mathrm{~mm}-\mathrm{Na}^{+}, 2.0 \mathrm{~mm}-\mathrm{Ca}^{2+}$ & 0.500 & $0.28 \pm 0.07$ & $0 \cdot 16 \pm 0.05$ & $0.93 \pm 0.01$ & $0 \cdot 19 \pm 0.04$ \\
\hline $0.5 \mathrm{~mm}-\mathrm{Na}^{+}, 1.0 \mathrm{~mm}-\mathrm{Ca}^{2+}$ & 0.500 & $0.22 \pm 0.04$ & $0 \cdot 12 \pm 0.05$ & $0.92 \pm 0.03$ & $0.16 \pm 0.06$ \\
\hline $0.356 \mathrm{~mm}-\mathrm{Na}^{+}, 0.5 \mathrm{~mm}-\mathrm{Ca}^{2+}$ & 0.500 & $0.26 \pm 0.06$ & $0.08 \pm 0.04$ & $0.94 \pm 0.02$ & $0 \cdot 17 \pm 0 \cdot 01$ \\
\hline $0.5 \mathrm{~mm}-\mathrm{Na}{ }^{+}, 0.5 \mathrm{~mm}-\mathrm{Ca}^{2+}$ & 0.707 & $0.10 \pm 0.05$ & $0.06 \pm 0.02$ & $0.90 \pm 0.03$ & $0.07 \pm 0.03$ \\
\hline
\end{tabular}

Several other monovalent cations enhanced thermal avoidance when present at $0.5 \mathrm{~mm}$ (Table 1). With the test arm at $40^{\circ} \mathrm{C}, \mathrm{Li}^{+}, \mathrm{Cs}^{+}$or hydroxylamine at $0.5 \mathrm{~mm}$ allowed better thermal avoidance than $0.5 \mathrm{mM}-\mathrm{Na}^{+}$, and $\mathrm{Rb}^{+}$was as effective as $\mathrm{Na}^{+}$at the same concentration. $\mathrm{K}^{+}$enhanced thermotaxis significantly at $1 \mathrm{~mm}$, but not at $0.5 \mathrm{~mm}$.

When the $\mathrm{Na}^{+}$concentration was held constant, raising the concentration of $\mathrm{Ca}^{2+}$ resulted in less thermal avoidance (Table 2) and greater migration upward, measured by $I_{\mathrm{m}}$. When $\left[\mathrm{Na}^{+}\right]$and $\left[\mathrm{Ca}^{2+}\right]$ were varied together so as to maintain a constant ratio $\left[\mathrm{Na}^{+}\right] /\left[\mathrm{Ca}^{2+}\right]^{\frac{1}{2}}, I_{\mathrm{T}}$ was essentially constant (Table 2 ), suggesting that it is this ratio, and not the absolute concentration of the ions, which determines thermosensitivity. Migration upward $\left(I_{\mathrm{M}}\right)$ was also unaffected as long as the ratio was constant.

\section{Effect of growth temperature on thermal avoidance threshold}

To determine whether the temperature at which thermal avoidance began was a function of the temperature at which cells were cultured, we compared thermotaxis in cells cultured at 15,28 and $35^{\circ} \mathrm{C}$ (Fig. 3). Cells cultured at these temperatures were pre-incubated in control solution for $5 \mathrm{~min}$ (rather than the usual $60 \mathrm{~min}$ ) at room temperature, and then assayed for their ability to avoid regions of 37 to $42^{\circ} \mathrm{C}$ (Fig. 3). The shorter pre-incubation reduced the chances that cells grown at 15 or $35^{\circ} \mathrm{C}$ would 'acclimatize' to room tempera- 


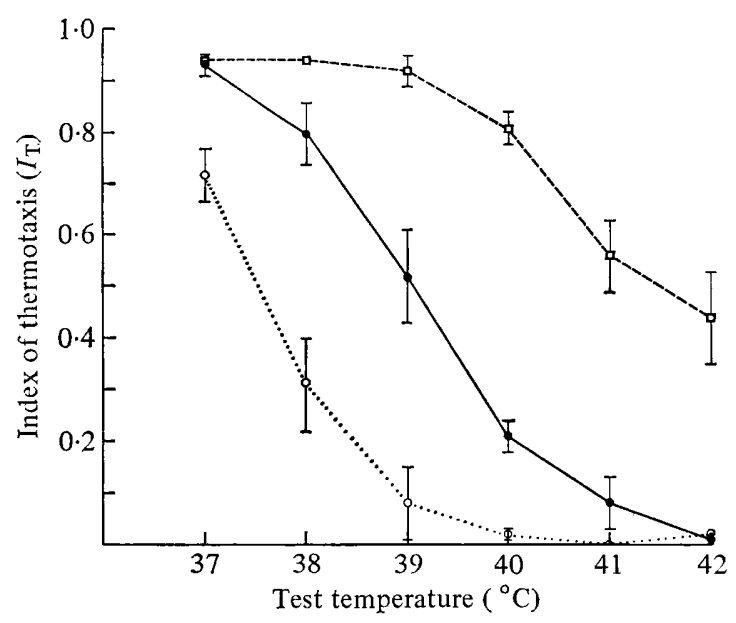

Fig. 3. Effect of growth temperature on thermal avoidance at six test temperatures. In all experiments the test solution was control solution with $0.5 \mathrm{~mm}-\mathrm{Na}^{+}$added. Cells were grown at $28(\bullet)$, $35(\square)$ or $15^{\circ} \mathrm{C}(\bigcirc)$. Mean values \pm standard deviations are shown; the number of experiments, $n$, was 4 , except for points with no error bars where $n=1$. With no heat applied to the test arm: $I_{\mathrm{T}}=0.93 \pm 0.04, I_{\mathrm{M}}=0.07 \pm 0.01$ for cells grown at $28^{\circ} \mathrm{C} ; I_{\mathrm{T}}=0.93 \pm 0.02, I_{\mathrm{M}}=0.09 \pm 0.02$ for cells grown at $35^{\circ} \mathrm{C} ; I_{\mathrm{T}}=0.93 \pm 0.03, I_{\mathrm{M}}=0.13 \pm 0.04$ for cells grown at $15^{\circ} \mathrm{C}$.

\section{Table 3. Effect on thermal avoidance of shift to $28^{\circ} \mathrm{C}$ after growth at 15 or $35^{\circ} \mathrm{C}$}

Cells were cultured for many generations at either 15 or $35^{\circ} \mathrm{C}$; they were then incubated at $28^{\circ} \mathrm{C}$ in Cerophyl medium (with bacteria) for the period indicated and assayed for avoidance of a $40^{\circ} \mathrm{C}$ region as described in Methods. For all experiments there were four independent trials.

$\begin{array}{cccc}\begin{array}{c}\text { Growth } \\ \text { temperature }\left({ }^{\circ} \mathrm{C}\right)\end{array} & \begin{array}{c}\text { Incubation time } \\ \text { at } 28{ }^{\circ} \mathrm{C}(\mathrm{h})\end{array} & I_{\mathrm{T}} & I_{\mathrm{M}} \\ 15 & 0 & 0 \cdot 02 \pm 0.01 & 0 \cdot 04 \pm 0.02 \\ 15 & 1 * & 0 \cdot 05 \pm 0.02 & 0 \cdot 03 \pm 0.02 \\ 15 & 24 & 0 \cdot 27 \pm 0 \cdot 04 & 0 \cdot 07 \pm 0.03 \\ 35 & 0 & 0 \cdot 81 \pm 0.03 & 0 \cdot 19 \pm 0.02 \\ 35 & 1 \dagger & 0 \cdot 49 \pm 0.06 & 0 \cdot 08 \pm 0.02 \\ 35 & 24 & 0 \cdot 23 \pm 0.06 & 0 \cdot 08 \pm 0.03 \\ 28 & 0 & 0 \cdot 21 \pm 0.03 & 0 \cdot 10 \pm 0.02\end{array}$

* Cultures shifted from 15 to $28^{\circ} \mathrm{C}$ had reached $22^{\circ} \mathrm{C}$ after $1 \mathrm{~h}$ and $28^{\circ} \mathrm{C}$ after $3 \mathrm{~h}$.

$\dagger$ Cultures shifted from 35 to $28^{\circ} \mathrm{C}$ had reached $30^{\circ} \mathrm{C}$ after $1 \mathrm{~h}$ and $28{ }^{\circ} \mathrm{C}$ after $3 \mathrm{~h}$.

ture, and control experiments with cells cultured at $28^{\circ} \mathrm{C}$ showed that neither $I_{\mathrm{T}}$ not $I_{\mathrm{M}}$ was significantly altered by the shorter pre-incubation. The temperature dependence of thermal avoidance reflected the temperature at which cells were cultured; for example, cells cultured at $35^{\circ} \mathrm{C}$ showed no avoidance at $38^{\circ} \mathrm{C}$, those cultured at $28^{\circ} \mathrm{C}$ showed measurable but not strong avoidance at $38^{\circ} \mathrm{C}$, and those cultured at $15^{\circ} \mathrm{C}$ showed strong avoidance. In all cases, avoidance increased with increasing temperature in the test arm, but for the cells grown at $35^{\circ} \mathrm{C}$, avoidance even at $42^{\circ} \mathrm{C}$ was incomplete. No experiments were done at higher temperatures because above $42{ }^{\circ} \mathrm{C}$ gross changes in morphology and behaviour were observed.

The displacements in the thermotaxis versus temperature profiles (Fig. 3) were smaller than the differences in culture temperature; half-maximal thermal avoidance $\left(I_{\mathrm{T}}=0.45\right)$ occurred at $37.7,39.2$ and $42{ }^{\circ} \mathrm{C}$, respectively, for cells cultured at 15,28 and $35^{\circ} \mathrm{C}$. In general, $I_{M}$ for cells grown at $35^{\circ} \mathrm{C}$ was somewhat higher than that for cells grown at $15^{\circ} \mathrm{C}(0 \cdot 13 \pm 0.05$ versus $0.04 \pm 0 \cdot 02$; Table 3$)$. 

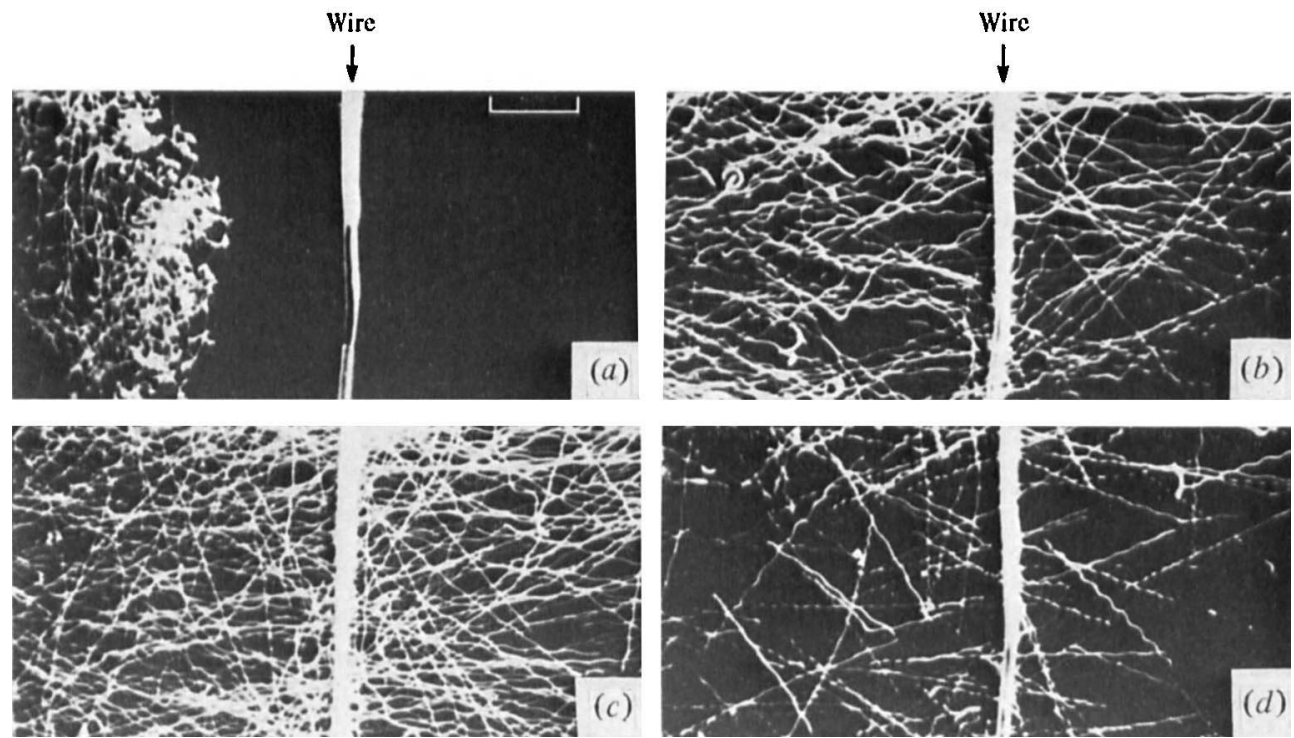

Fig. 4. Swimming behaviour on approach to a heated wire. Dark-field photographs (time exposures) were taken as described in Methods, with cells in $0.5 \mathrm{mM}-\mathrm{NaCl}$. Wild-type $(a, c)$ or Pawn $\mathbf{B}(b, d)$ cells were initially added to the left side and are swimming from left to right in the photographs. In $(a)$ and $(b)$, the wire was heated to give a temperature of about $40^{\circ} \mathrm{C}$ at the wire; $(c)$ and $(d)$ are unheated controls. Light tracks represent the swimming path of individual cells. Bar marker (in $a$ ) represents $0 \cdot 1 \mathrm{~cm}$.

When cells in the exponential phase of growth at 15 or $35^{\circ} \mathrm{C}$ were transferred to medium containing bacteria at $28^{\circ} \mathrm{C}$, they re-acquired within $24 \mathrm{~h}$ the thermal avoidance characteristic of cells cultured at $28{ }^{\circ} \mathrm{C}$ (Table 3).

\section{Effects of $p H$ and buffer}

Preliminary experiments suggested that thermal avoidance behaviour was sensitive to $\mathrm{pH}$, and in view of the strong dependence of the $\mathrm{p} K$ of Tris on temperature $\left(\Delta \mathrm{p} K / \Delta^{\circ} \mathrm{C}=\right.$ -0.031 ), it was necessary to establish whether the important gradient in these experiments was of $\mathrm{pH}$ or of temperature. When $\operatorname{MOPS}\left(\Delta \mathrm{p} K / \Delta^{\circ} \mathrm{C}=-0.006\right)$ was substituted for Tris in our assay, no change in either $I_{M}$ or $I_{T}$ was observed.

\section{Behaviour of Pawn mutants}

Pawn mutants, selected for their inability to reverse swimming direction in response to stimulation, and known to be defective in the $\mathrm{Ca}^{2+}$ channel of the excitable membrane (Kung \& Eckert, 1972), showed grossly defective thermal avoidance (Fig. 2). Pawn A, a slightly leaky mutant (Chang et al., 1974), showed barely significant avoidance at 41 or $42{ }^{\circ} \mathrm{C}$, and none at all at lower temperatures, and Pawn B (non-leaky) showed no avoidance at any temperature tested. Values of $I_{\mathrm{M}}$ were the same for both Pawn mutants, and were essentially unaltered by the test temperature (data not shown). In $1 \mathrm{mM}-\mathrm{Na}^{+}, I_{\mathrm{M}}$ for both Pawn mutants was two to three times higher than $I_{M}$ for wild-type cells, presumably because the latter underwent frequent spontaneous changes of direction and therefore had shorter mean free paths.

\section{Behaviour on approach to a hot wire}

Dark-field time exposures (Fig. 4) allowed us to record the behaviour of individual cells as they approached an area warmed by a hot wire. Wild-type cells cultured at $28^{\circ} \mathrm{C}$ performed a series of avoiding reactions as they entered a region of about $40^{\circ} \mathrm{C} \mathrm{(Fig.} 4 \mathrm{a}$ ), but Pawn B mutants swam into and through the warm region with no interruption of their 
paths (Fig. $4 b$ ). In a control experiment, wild-type cells swam past the wire when it was unheated (Fig. 4c), as did Pawn B mutants (Fig. 4d). Thermal avoidance in this experimental situation is accomplished by classical avoidance reactions involving temporary ciliary reversal, a fact well documented in the cine film by Schlieper (1937). We have not attempted to quantify the velocity of swimming from the dark-field photographs; it is possible that some alteration in velocity also resulted from the thermal stimulus.

\section{DISCUSSION}

The assay described here gives a quantitative and highly reproducible measure of thermal avoidance behaviour in Paramecium. The natural tendency to swim upward (negative geotaxis) is counterbalanced by the tendency to avoid a warm region, and when the upper arm of the apparatus is warmer than about $40{ }^{\circ} \mathrm{C}$, the latter tendency dominates. The assay should be applicable to any free-swimming, geotactic organism.

The ionic composition of the assay medium proved to be an important factor in thermal avoidance; increasing concentrations of monovalent cations or decreasing concentration of $\mathrm{Ca}^{2+}$ resulted in stronger avoidance at a given temperature, and lowered the thermal avoidance threshold. More important than the concentration of a given ion was the ratio of [monovalent cation] $/\left[\mathrm{Ca}^{2+}\right]^{\frac{1}{2}}$ (the Donnan ratio). Previous studies of excitability (Naitoh \& Eckert, 1968) and behaviour (Kamada \& Kinosita, 1940; Jahn, 1962; Grebecki, 1965) revealed a similar dependence on the Donnan ratio and led to the proposal (Naitoh, 1968) that monovalent cations displace $\mathrm{Ca}^{2+}$ from a surface binding site, making $\mathrm{Ca}^{2+}$ available to activate the reversal mechanism. High concentrations of monovalent cations displaced surface-bound $\mathrm{Ca}^{2+}$ (Naitoh \& Yasumasu, 1967) and elicited classical avoidance reactions (Jahn, 1962; Grebecki, 1965) to an extent proportional to the Donnan ratio.

Thermal avoidance showed a remarkably sharp dependence on temperature; cells cultured at $28{ }^{\circ} \mathrm{C}$ showed barely measurable avoidance at $38{ }^{\circ} \mathrm{C}$ but virtually complete avoidance at $41^{\circ} \mathrm{C}$. We found that the exact temperature at which thermal avoidance occurred depended on the growth temperature; cells cultured at higher temperatures required higher temperatures to produce the avoidance behaviour. Thus, the thermosensory transducer is able somehow to acclimatize to different growth temperatures.

Glaser (1924) and Yapp (1941) studied the swimming velocity of Paramecium as a function of temperature and both reported that velocity increased with temperature. Yapp noted that when the temperature exceeded about $30{ }^{\circ} \mathrm{C}$, the frequency of avoiding reactions increased dramatically, so that forward motion practically ceased. Tawada \& Oosawa (1972) and Tawada \& Miyamoto (1973) documented the occurrence of orthokinesis (alteration of swimming velocity) in Paramecium subjected to thermal stimulus near the culturing temperature, but more recently Nakaoko \& Oosawa (1977) have reported that klinokinesis (alteration in the frequency of direction changes) is primarily responsible for the accumulation of Paramecium at an optimal temperature in at least certain strains of Paramecium.

Our results show that thermal avoidance is accomplished at least in part by klinokinesis. The most direct demonstration of this presented here is the dark-field photographs (Fig. 4) which show sharp changes in swimming direction as cells enter a region of about $40^{\circ} \mathrm{C}$. Schlieper (1937) previously used micro-cinematography to document heat-induced avoiding reactions in Paramecium caudatum, and Hildebrand \& Dryl (personal communication) have also made the same observation with Paramecium caudatum. The failure of Pawn B to show thermal avoidance further suggests that classical avoidance reactions are involved; this mutant cannot reverse its swimming direction, but shows negative geotaxis (Kung, 1971).

We considered it possible that what we call 'avoidance' is simply immobilization caused by elevated temperature. We have determined in separate experiments the temperature at which cells become immobile. Both Pawn and wild-type cells were motile at $40^{\circ} \mathrm{C}$, but 
incubation at $41^{\circ} \mathrm{C}$ or higher eventually (within $5 \mathrm{~min}$ ) caused immobilization of both types. The fact that Pawn cells were not capable of thermal avoidance in our T-tube assay at temperatures that wild-type cells avoided completely indicates that avoidance is not due merely to immobilization.

The experiments described here with Pawn mutants indicate that the mechanism responsible for thermal avoidance shares at least some components with the mechanism(s) involved in responses to chemical and other physical stimuli. For example, a functional $\mathrm{Ca}^{2+}$ channel is apparently necessary for thermal avoidance.

What is the molecular nature of the thermoreceptor? The molecule(s) must undergo some change, presumably conformational, in response to a change of 1 to $2{ }^{\circ} \mathrm{C}$ in temperature. It must also be able to acclimatize to different culture temperatures by changing the absolute temperature at which this transition occurs. A protein could certainly change conformation with a change in temperature, but it seems highly unlikely that a single protein could acclimatize as the thermoreceptor must. Membrane lipids undergo sharp phase transitions or phase separations at temperatures near the physiological range, and the exact temperature of the transition depends on the type of lipid(s) present in the membrane (e.g. Overath et al., 1970; McElhaney \& Souza, 1976; Sinensky, 1971, 1974; Cossins, 1977; Wunderlich et al., 1973; Kitajima \& Thompson, 1977; Nandini-Kishore et al., 1977). Cells cultured at higher temperature tend to have more saturated fatty acids in their lipids, and to undergo the 'solid' to 'fluid' phase change at higher temperatures, than cells cultured at lower temperatures (Overath et al., 1970; McElhaney \& Souza, 1976; Sinensky, 1971, 1974; Wunderlich et al., 1973). Studies of a variety of prokaryotes (e.g. McElhaney \& Souza, 1976; Sinensky, 1974; Gill \& Suisted, 1978) and eukaryotes including the related ciliate protozoon Tetrahymena (Cossins, 1977; Nandini-Kishore et al., 1977; Wunderlich et al., 1973) show that cells alter their membrane lipid composition in response to factors such as changed growth temperature, apparently striving to maintain a constant fluidity of membrane lipid. There is ample evidence that thermally induced alterations in membrane lipid fluidity alter the activity of intrinsic membrane proteins (e.g. Farias et al., 1975; Thilo et al., 1977). Thus, membrane lipids have the basic properties required of a thermoreceptor. Poff \& Skokut (1977) have also pointed this out in connection with their studies of thermotaxis in Dictyostelium discoideum.

Several lines of evidence suggest that in Paramecium some membrane lipid(s), perhaps associated with a specific ion channel, may be the primary thermoreceptor. The excitable portion of the Paramecium membrane is the ciliary membrane (Dunlap, 1977; Ogura \& Takahashi, 1976), which also has a lipid composition distinctly different from that of other cellular membranes (Rhoads \& Kaneshiro, 1979; Andrews \& Nelson, 1979). Physical studies of the membranes of Tetrahymena suggest that the ciliary membrane is the least fluid of all cellular membranes of that organism (Thompson \& Nozawa, 1977). Local anaesthetics, such as tetracaine, which may act by making membrane lipids more fluid (Lee, 1976; Hayden et al., 1977) elicit strong avoidance reactions in Paramecium (Browning \& Nelson, 1976). Paramecium grown at high temperature $\left(35^{\circ} \mathrm{C}\right)$ shows virtually no response at $15^{\circ} \mathrm{C}$ to the chemical stimulant $\mathrm{Ba}^{2+}$, although cells both cultured and assayed at $15{ }^{\circ} \mathrm{C}$ are normally responsive (Thiede, Kung \& Fielder, unpublished observations). Finally, the experiments described here indicate that the thermal avoidance threshold varies with growth temperature.

Our present working hypothesis is this: some lipid species closely associated with an ion gate in the Paramecium membrane (e.g. the $\mathrm{Ca}^{2+}$ or $\mathrm{K}^{+}$gate) can influence the opening and closing of the gate. Any factor that makes that lipid more fluid will tend to depolarize the membrane; this might be brought about, for example, by opening the $\mathrm{Ca}^{2+}$ channel or closing the $\mathrm{K}^{+}$channel. One such factor is an increase in temperature; ionic composition of the medium may be another (Trauble \& Eibl, 1974). 
This research was supported by grants from the National Science Foundation (BNS 7611490), the Graduate School of the University of Wisconsin, and a Dreyfus Foundation Teacher-Scholar Award to D.L.N. D.L.N. is the recipient of a Research Career Development Award (NIH 00085) and a Steenbock Career Advancement Award. T.H. is a predoctoral fellow in the Neurosciences Program, University of Wisconsin. We thank Ching Kung and Julius Adler for their helpful comments on this manuscript.

\section{REFERENCES}

ANDrews, D. \& Nelson, D. L. (1979). Biochemical studies of the excitable membrane of Paramecium tetraurelia. II. Phospholipids of ciliary and other membranes. Biochimica et biophysica acta 550, 174-187.

Browning, J. L. \& Nelson, D. L. (1976). Amphipathic amines affect membrane excitability in Paramecium: role for bilayer couple. Proceedings of the National Academy of Sciences of the United States of America 73, 452-456.

Chang, S. Y. \& Kung, C. (1973). Temperature sensitive Pawns: conditional behavioral mutants of Paramecium aurelia. Science 180, 1197-1199.

Chang, S. Y., Van Houten, J., Robels, L. R., Lui, S. S. \& KUNG, C. (1974). An extensive behavioral and genetic analysis of the Pawn mutants -in Paramecium aurelia. Genetical Research 23, 165173.

Cossins, A. R. (1977). Adaptation of biological membranes to temperature. The effect of temperature acclimation of goldfish upon the viscosity of synaptosomal membranes. Biochimica et biophysica acta 470, 395-411.

DUNLAP, K. (1977). Localization of calcium channels in Paramecium caudatum. Journal of Physiology 271, 119-133.

ECKERT, R. (1972). Bioelectric control of cilia. Science 176, 473-481.

Farias, R., Bloj, B., Morero, R. D., Sineriz, F. \& TRuCCO, R. E. (1975). Regulation of allosteric membrane-bound enzymes through changes in membrane lipid composition. Biochimica et biophysica acta 415, 231-252.

GiLl, C. O. \& SuISTED, J. R. (1978). The effects of temperature and growth rate on the proportion of unsaturated fatty acids in bacterial lipids. Journal of General Microbiology 104, 31-36.

Glaser, O. (1924). Temperature and forward movement of Paramecium. Journal of General Physiology 7, 177-188.

GrEBECKI, A. (1965). Role of $\mathrm{Ca}^{2+}$ ions in the excitability of protozoan cell. Decalcification, recalcification and the ciliary reversal in Paramecium caudatum. Acta protozoologica 3, 275289.

Hayden, D. A., Hendry, B. M., Levinson, S. R. \& RequenA, J. (1977). The molecular mechanisms of anaesthesia. Nature, London 268, 356-358.

HedGECOCK, E. M. \& RuSSELL, R. L. (1975). Normal and mutant thermotaxis in the nematode Caenorhabditis elegans. Proceedings of the National Academy of Sciences of the United States of America 72, 4061-4065.

JAHN, T. L. (1962). The mechanism of ciliary movement. II. Ion antagonism and ciliary rever- sal. Journal of Cellular and Comparative Physiology 60, 217-228.

JENNINGS, H. S. (1904). Reaction to heat and cold in the ciliate infusoria. Contributions to the study of lower organisms. Carnegie Institute of Washington Publication, no. 16, 5-28.

JENNINGS, H. S. (1906). Behavior of Lower Organisms, pp. 51-58. Bloomington, Indiana: Indiana University Press.

Kamada, T. \& Kinosita, H. (1940). Proceedings of the Imperial Academy of Japan 16, 125.

Kitajima, Y. \& THOMPSON, G. (1977). Self-regulation of membrane fluidity. The effect of saturated normal and methoxy fatty acid supplementation on Tetrahymena membrane physical properties and lipid composition. Biochimica et biophysica acta 468, 73-80.

KunG, C. (1971). Genic mutants with altered system of excitation in Paramecium aurelia. Zeitschrift für vergleichende Physiologie 71, 142-164.

KUNG, C. \& ECKerT, S. R. (1972). Genetic modification of electric properties in an excitable membrane. Proceedings of the National Academy of Sciences of the United States of America 69, 93-97.

Kung, C., Chang, S. Y., Satow, Y., Van Houten, J. \& Hansma, H. (1975). Genetic dissection of behavior in Paramecium. Science 188, 898-904.

LEE, A. G. (1976). Model for action of local anaesthetics. Nature, London 262, 545-548.

Maeda, K., Imae, Y., ShoI, J.-I. \& Oosawa, F. (1976). Effect of temperature on motility and chemotaxis of Escherichia coli. Journal of Bacteriology 127, 1039-1046.

McElhaney, R. N. \& SouzA, K. A. (1976). The relationship between environmental temperature, cell growth, and the fluidity and physical state of the membrane lipids in Bacillus stearothermophilus. Biochimica et biophysica acta 443, 348-359.

Mendelssohn, M. (1902a). L'interference de la thermotaxie avec d'autres tactismes et sur le mecanisme du mouvement thermotactique. Journal de physiologie et de pathologie générale 4, 475-488.

Mendelssohn, M. (1902b). Quelques considerations sur la nature et le role biologique de la thermotaxie. Journal de physiologie et de pathologie générale 4, 489-496.

MENDELSSOHN, M. $(1902 c)$. Recherches sur la thermotaxie des organismes unicellulaires. Journal de physiologie et de pathologie générale 4, 393-409.

NaITOH, Y. (1968). Ionic control of the reversal response of cilia in Paramecium caudatum. A calcium hypothesis. Journal of General Physiology 51, 85-103. 
NAITOH, Y. \& ECKERT, R. (1968). Electrical properties of Paramecium caudatum: modification by bound and free cations. Zeitschrift für vergleichende Physiologie 61, 427-452.

NaIToH, Y. \& YASUMASU, I. (1967). Binding of Ca ions by Paramecium caudatum. Journal of General Physiology 50, 1303-1310.

NAKaOKo, Y. \& OosaWA, F. (1977). Temperaturesensitive behavior of Paramecium caudatum. Journal of Protozoology 24, 575-580.

NANDini-Kishore, S., KitaJima, Y. \& ThOMPSON, G. (1977). Membrane fluidizing effects of the general anaesthetic methoxyfluorane elicits an acclimation response in Tetrahymena. Biochimica et biophysica acta 471, 157-161.

Nelson, D. L. \& Kung, C. (1978). Behavior of Paramecium - chemical, physiological and genetic studies. In Taxis and Behavior (Receptors and Recognition, series B, vol. 5), pp. 77-100. Edited by G. L. Hazelbauer. London: Chapman \& Co.

Ogura, A. \& TAKahashi, K. (1976). Artificial deciliation causes loss of $\mathrm{Ca}^{++}$-dependent responses in Paramecium. Nature, London 264, 170172.

OosaWA, F. (1976). Thermotaxis of microorganisms. Journal of Biochemistry 79, 49-50.

Overath, P., Schairer, H. U. \& Stoffel, W. (1970). Correlation of in vivo and in vitro phase transitions of membrane lipids in Escherichia coli. Proceedings of the National Academy of Sciences of the United States of America 67, 606-612.

PoFf, K. L. \& Skokut, M. (1977). Thermotaxis by pseudoplasmodia of Dictyostelium discoideum. Proceedings of the National Academy of Sciences of the United States of America 74, 2007-2010.

Rhoads, D. E. \& Kaneshiro, E. S. (1979). Characterization of phospholipids from Paramecium tetraurelia cells and cilia. Journal of Protozoology (in the Press).

SCHLIEPER, C. (1937). Reizphysiologische Versuche an Paramecium caudatum. Film no. C214. Göttingen: Institut für den Wissenschaftlichen Film.
Sinensky, M. (1971). Temperature control of phospholipid biosynthesis in E. coli. Journal of Bacteriology 106, 449-455.

SINENSKY, M. (1974). Homeoviscous adaptation a homeostatic process that regulates the viscosity of membrane lipids in Escherichia coli. Proceedings of the National Academy of Sciences of the United States of America 71, 522-525.

SONNEBorN, T. M. (1950). Methods in the general biology and genetics of Paramecium aurelia. Journal of Experimental Zoology 113, 87-148.

TAWAda, K. \& MiYamoto, H. (1973). Sensitivity of Paramecium thermotaxis to temperature change. Journal of Protozoology 20, 289-292.

TAWADA, K. \& Oosawa, F. (1972). Responses of Paramecium to temperature change. Journal of Protozoology 19, 53-57.

Thilo, L., Trauble, H. \& Overath, P. (1977). Mechanistic interpretation of the influence of lipid phase transitions on transport functions. Biochemistry 16, 1283-1290.

THOMPson, JR, G. A. \& Nozawa, Y. (1977). Tetrahymena: a system for studying dynamic membrane alterations within the eukaryotic cell. Biochimica et biophysica acta 472, 55-92.

Trauble, H. \& EIBL, H. (1974). Electrostatic effects on lipid phase transitions: membrane structure and ionic environment. Proceedings of the National Academy of Sciences of the United States of America 71, 214-219.

Tso, W. \& Mansour, T. E. (1975). Thermotaxis in a slime mold, Physarum polycephalum. Journal of Behavioral Biology 14, 499-504.

Van Houten, J., Hansma, H. \& Kung, C. (1975). Two quantitative assays for chemotaxis in Paramecium. Journal of Comparative Physiology 104, 211-223.

Wunderlich, F., SPeth, V., BAtz, W. \& KLeINIG, H. (1973). Membranes of Tetrahymena. III. The effect of temperature on membrane core structures and fatty acid composition of Tetrahymena cells. Biochimica et biophysica acta 298, 39-49.

YAPP, W. B. (1941). Klinokinesis of Paramecium. Nature, London 148, 754. 